\title{
Intercultural Theology and Philosophical Theology
}

\author{
DaVID CheETHaM
}

\section{University of Birmingham}

\section{Introduction}

Students at my own faculty at Birmingham University-especially those whose degrees straddle both the Theology and Philosophy departmentshave sometimes expressed exasperation concerning differing essay writing guidelines. How many books or articles should be used for essays? The answers they receive are differentiated according to discipline. If the more theological or religious studies essays should aim to show a range of sources - historical, textual, dogmatic, philosophical, contextual-the philosophical ones tend to stress the virtues of constructing a sound and extended argument without the clutter of too many sources or citations. Put another way, we could say that one is concerned with proper contextualisation and pedigree, and the other with decontextualized analysis. ${ }^{1}$

This is a pedagogic aspect that might exemplify the deep fault lines between contextual theologies and those approaches, such as philosophical theology, that attempt to provide a rational analysis of the content of faith, creeds and beliefs. Indeed, the approach of the latter is often seen as taking place within a mostly occidental horizon - which further reinforces the suspicion that cultural (and more so inter-cultural) theology and philosophical theology are uneasy bedfellows (Wimmer 1996). It is important to recognise that this is the case even when we consider some well-known philosophies of religious pluralism. Prima facie, the attempt to address the sheer fact of diversity would suggest interculturality as a natural habitus, but a hypothesis about religious plurality may be an attempt to get to the bottom of the differences by providing an explanatory framework that seeks to retain the coherence of some aspect that is deemed crucial: for example, the transcendent or the supernatural, the "Real" or the good. In which case, even if the data being considered happens to be the rich diversity of religious and cultural pluralism, there is still a motion towards pursuing the transcultural precision of conceptual thinking that helps to tidy up the cultural clutter of particular religious phenomena. In this sense, notwithstanding his desire to pursue a religious interpretation of religion, John Hick's philosophy of religious pluralism is still a thoroughgoing exercise in philosophy - the attempt to go behind differences and

1 This is certainly the case at Birmingham where the Philosophy Department is overwhelmingly analytic, rather than continental, in its approach. 
defend a critically realist understanding of religious beliefs - which is, paradoxically, more of a philosophical than intercultural priority. So, what is a genuinely intercultural philosophical theology and how might it be practised?

\section{Intercultural Theology_Discerning its Field}

Most historians see one of the chief sources of intercultural theology to be the growing dissatisfaction with missiology in the 1970s (see Ustorf 2008 and Friedl 1987), combined with a growing body of theological literature on other faiths, cultural difference and postcolonial guilt. Missiologists became increasingly frustrated with what they viewed as hackneyed missiological methods and dogmatic certainties and proposed paying greater attention to ecumenism, historical and contextual scholarship and the subtleties of inter-cultural and inter-religious encounter. Thus, many chairs in missiology have now been rebranded along the lines of "intercultural theology/studies."

Nevertheless intercultural theology is often grouped synonymously with other programmes like comparative theology, global theology, ecumenical theology or even the theology of religions. ${ }^{2}$ Moreover, the parallel development of intercultural philosophy - stemming from the German academic scene with thinkers such as Raúl Fornet-Betancourt, Ram Adhar Mall and Franz Wimmer-has obviously not been concerned with missiology but with the need to recognize of the diverse global (rather than solely Western) philosophical traditions. Thus, whatever their origins, both intercultural theology and philosophy are clearly being associated with more global agendas and diversity.

Frans Wijsen of Nijmegen argues that often what passes as intercultural theology is actually comparative theology (Wijsen 2014:190) ${ }^{3}$ and he would press for a more discrete identity. Thus, he proposes to view it as an attitude that is somewhat internalised by the practitioner: "cross-cultural communication does not show differences, but brings them about [...] I cannot only take the position of the other; the other is already part of me. He or she is not totally strange to me" (Wijsen 2014: 191).

In similar vein, Wimmer describes intercultural philosophy as a "new

2 Of course the European Society for Intercultural Theology and Interreligious Studies (ESITIS), with which the author has had a long involvement, is one example of intercultural theology being closely linked with such agendas.

3 His examples include the distinguished introductory works by Hock 2011 and Kuster 2011.

(C) Equinox Publishing Ltd. 2017

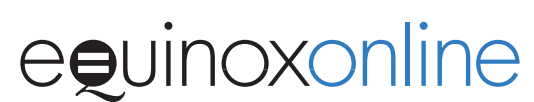


orientation in philosophy." That is, rather than focussing on the material of intercultural thinking, it needs to be understood as a way of thinking. Rather than being "just another exotism" it is "fundamental for every thinking which knows about the cultural contingency of all modes of thinking, and yet aims to know" (Wimmer 1996, 2). In light of the history of Western philosophy, this might hardly sound like a radical proposalthat we should recognise that our thinking is framed within our own human structures - at least this is already a fundamental aspect of the Kantian tradition. However, it should certainly challenge any implicit assumption that philosophical thinking is practised "correctly" by the West alone.

\section{Philosophical Theology and Intercultural Arguing}

The fortunes of philosophical theology have improved in recent times (see Flint and Rea 2009; Wolterstorff 2009). Indeed, its current flourishing may owe itself to developments in the field of philosophy that also have implications for the fortunes of intercultural thinking, too.

Two chief factors that Nicholas Wolterstorff thinks influenced the emergence of philosophical theology and its recent flourishing are, first, the decline of the influence of logical positivism with its strict verificationist demands and, second, the rise of meta-epistemology and its challenge to the consensus about epistemological theory $(2009,162)$. The latter entails a "stepping back" that surveys the whole range of epistemological possibilities and considers classical foundationalism to be just one theory of knowledge. This means that philosophical theology (and other similar branches of philosophy) does not necessarily have to satisfy a rational checklist of certitudes. Additionally, we might also note that the diversification of epistemological warrants permits a range of different cultural philosophical discourses to gain a hearing.

Additionally, the notion of public reason has been questioned in analytic philosophy. Although this might have been an important ingredient in John Rawls' political philosophy it is, even as a political postulate for the public sphere, a problematic idea for philosophic reasoning in general. Wolterstorff critiques the idea of "public philosophical reason" as a basis for philosophical argumentation. He notes that disputes between Stoics, Neoplatonists, Skeptics or Christians did not seem to presuppose some "foundationalist" reason as a prerequisite for debate but "simply met each other in the public arena and started discussing and arguing" (Wolterstorff 2009, 166). John Clayton makes a similar observation, alluding, however, not to the Greek but to the vada tradition of debate in India where disputes

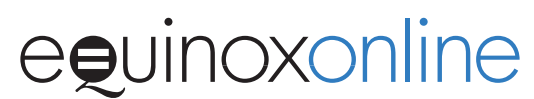


might take place between Brahminic, Jaina or Buddhist schools and where "[c]ontestability, not neutrality, was the price of entry to the public arena" $(2006,72)$.

Wolterstorff thinks that few contemporary philosophers of the analytic tradition assume the "classical foundationalist" view but take a practical or ad hoc approach:

When moving beyond developing his views to presenting them to his fellow philosophers, he cites the considerations that he has found true and relevant. He hopes that some of his fellow philosophers will find his arguments sound. If some do find them sound [...][i]t will not be because he has seen to it that the premises of his arguments have all been drawn from the content of public philosophical reason. $(2009,165)$

So, as Wolterstorff presents this as a "dialogic pluralism" $(2009,166)$, we have a warrant for adding interculturality into the mix. We enter public debate with our best arguments, relying not on a neutral ground of reason, still less assuming a Western procedure of thinking but hoping that our arguments may resonate with the cultural and religious other. At least, we are challenged to ensure that our arguments possess a certain contestability (Clayton) but, further than this, perhaps we also enter with a new outlook (Wijsen; Wimmer). This outlook is intercultural-not merely a dialogical debate between scholars from differing philosophical and cultural traditions but also a "internalisation of interculturality" that is perhaps afforded in the twenty-first-century experience of a variety of media which bring the world into our immediate proximity.

Notwithstanding this new orientation that prohibits the assumption that just one philosophical tradition holds all the cards, we might recall Wimmer's comment earlier that-whilst acknowledging our cultural contingency - "we aim to know." That is, there is still the fundamental eros of philosophy that seeks to pursue deeper understanding and truth. In this regard, we ought not to use interculturality as an embargo against such aims and simultaneously expect dialogue between intercultural theology and philosophical theology to flourish. Instead, liberated from the notion of "public reason," we might see an intercultural agenda as an invitation to find new angles on, and new arguments to tackle, old theological dilemmas and doctrines. 


\section{References}

Clayton, John. 2006. Religions, Reasons and Gods: Essays in Cross-Cultural Philosophy of Religion. Cambridge: Cambridge University Press. https:// doi.org/10.1017/CBO9780511488399

Flint, Thomas P. and Michael C. Rea. 2009. "Introduction." In The Oxford Handbook of Philosophical Theology, edited by in T.P. Flint and M.C. Rea, 1-7. Oxford: Oxford University Press. https://doi.org/10.1093/ oxfordhb/9780199289202.003.0001

Friedl, Richard. 1987. "Interkulterelle Theologie." In Lexicon Missionstheologischer Grundbegriffe, edited by Muller, K and Sundermeier, 181-185. Berlin: Reimer.

Hock, K. 2011. Einführung in the Interkuturelle Theologie. Darmstadt: WBG.

Kuster, V. 2011. Einführung in die Interkulturelle Theologie. Göttingen: Vandenhoeck and Ruprecht.

Marion, Jean-Luc 2008. The Visible and the Revealed. New York: Fordham University Press.

Ustorf, Werner. 2008. "The Cultural Origins of "Intercultural Theology." Mission Studies 25(2): 229-251. https://doi.org/10.1163/157338308X365387

Wijsen, Frans. 2014. "What is Intercultural about Intercultural Theology?" Gema Teologi 38(2): 185-192.

Wimmer, Franz. 1996. "Is Intercultural Philosophy a New Branch or a New Orientation in Philosophy?" In Interculturality of Philosophy and Religion, edited by Gregory D'Souza, 45-57. Bangalore: National Biblical Catechetical and Liturgical Centre.

Wolterstorff, Nicholas. 2009. "How Philosophical Theology became possible within the Analytic Tradition of philosophy." In Analytic Theology: New Essays in the Philosophy of Theology, edited by O.D. Crisp and M.C. Rea, 155-168. Oxford: Oxford University Press. https://doi.org/10.1093/ acprof:oso/9780199203567.003.0008

David Cheetham teaches Philosophical Theology. Email: d.cheetham@bham.ac.uk

(C) Equinox Publishing Ltd. 2017

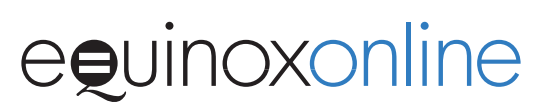

